\title{
An Attractant contained in Actinidia polygama MiQ. for Male Lace Wing, Chrysopa septenpunctata WESMAEL ${ }^{1}$
}

\author{
By Shoziro IsHII
}

\author{
Pesticide Research Institute, College of Agriculture, Kyoto University, Kyoto, Japan
}

It has been observed that male adults of lace wing, Chrysopa septenpunctata Wesmael, Chrysopidae, are highly attracted by a kind of vine plant "Matatabi" Actinidia polygama MrQ. belonging to Actinidiaceae (YANo, 1931; Ishimori, 1931; TAKAGI, 1932). However, the chemical nature of the active principle has not been studied.

In order to know this active principle, an attempt was made to isolate it from fruits of this plants, and some biological tests were carried out.

\section{MATERIAL AND METHODS}

\section{Fruits of Actinidia polygama}

Materials used for the extraction were fruits of Actinidia polygama collected at Nogurizawa, mountainous parts of Gumma Prefecture at the end of July, 1962. More than half of the fruits were galls caused by parasitism with Asphondylia sp., Cecidomyiidae. Before the extraction, the fruits and galls were submitted for biological tests separately, and both were confirmed to be attractive to the lace wings.

Biological assay

Extracts from the fruits were diluted with ethanol, and dropped on a filter paper, with a capillary tube. The filter papers impregnated with the extracts were set in a garden in the evening. If male lace wings distribute in that area, they are attracted by the filter paper at night as shown in Fig. 1. The attracted insects bite the filter paper by their mandibles, and leave a characteristic mark on the paper as shown in Fig. 2.

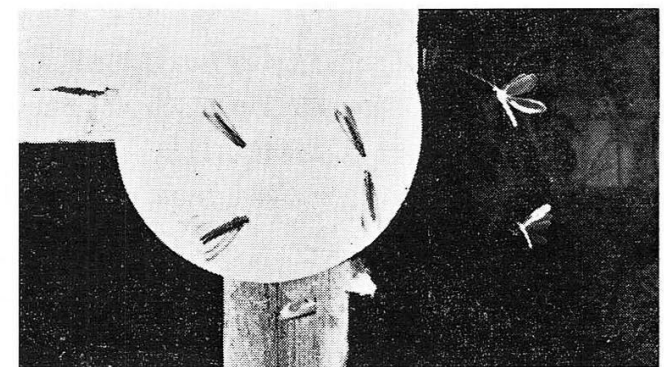

Fig. 1. Male lace wings, Chrysopa septenpunctata, are attracted to a filter paper impregnated with the extract of Actinidia polygama.

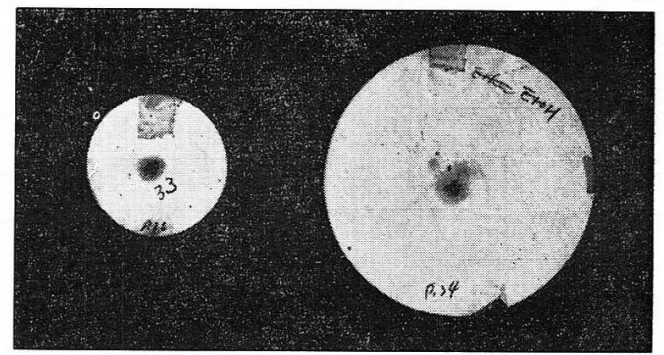

Fig. 2. Marks left on filter papers which were impregnated with the cxtract of Actinidia polygama by bitting of male lace wings, Chrysopa septenpunctata.

\section{ISOLATION AND RESULTS OF BIOLOGICAL ASSAY}

The fruits and galls, $3.5 \mathrm{~kg}$, were minced by a meat grinder. Minced fruits were extracted with ether. Since the ether extract showed the activity, the extract was fractionated to acidic, neutral and basic fractions, and each fraction was submitted for biological assay. Results of the bioassay clearly indicated that the neutral fraction contains active substance(s).

1 This paper has been read at the Annual Meeting of the Japanese Society of applied Entomology and Zoology held on April 2, 1964 at the University of Tokyo. (Received for publication, August 24, 1964) 
The neutral substances $(12.8 \mathrm{~g})$ were steam-distillated, and the distillate $(1.4 \mathrm{~g})$ and residue were collected. The active substance(s) was contained in the steam distillate.

About $300 \mathrm{mg}$ of the steam distillate was fractionated by column chromatography on $12 \mathrm{~g}$ of Woelm neutral alumina, $5 \mathrm{~mm}$ $\times 190 \mathrm{~mm}$. The distillate was stepwisely eluted with each $100 \mathrm{ml}$ of $n$-hexane, 10,25 and 50 per cent of ether in $n$-hexane, 90 $\mathrm{ml}$ of ether and $100 \mathrm{ml}$ of ethanol.

The lace wings were attracted by the eluent with ethanol. This eluent was pale yellow oily substance with a characteritic fragrance.

The alcoholic eluent was rechromatographed on a mixture of $5 \mathrm{~g}$ of Mallinckrodt silicic acid and $5 \mathrm{~g}$ of celite, and eluted stepwisely with $100 \mathrm{ml}$ of $n$-hexane, $100 \mathrm{ml}$ of 50 per cent ethanol in $n$-hexane and 90 $\mathrm{ml}$ of ethanol. The eluents were collected each $3 \mathrm{ml}$ by using a fraction collector. Nos. 31 to 37 of flasks showed activity to the lace wings.

These eluents were pooled and rechromatographed by using same column with silicic acid $5 \mathrm{~g}$ and celite $4 \mathrm{~g} . \quad 30 \mathrm{ml}$ of $n$ hexane, $90 \mathrm{ml}$ of 10 per cent ethanol in $n$-hexane and $50 \mathrm{ml}$ of ethanol were used as solvents. Nos. 7 to 12 showed highly activity to the insects.

Since infrared spectrum of the oil obtained by the steam-distillation showed lactone bands in addition to alcoholic bands, $80 \mathrm{mg}$ of the steam-distillate of the neutral substance was warmed with 5 per cent of aqueous solution of $\mathrm{NaOH}$ in a water bath at $70^{\circ} \mathrm{C}$ for 2.5 hours to remove lactone. After the treatment, the mixture was extracted with ether. The ether was evaporated off, and yellowish oil was obtained. This oil showed attractiveness to the lace wings. Repeated treatment with 5 per cent aqueous $\mathrm{NaOH}$ was carried out under same conditions for 80 minutes to make sure absence of the lactone. After evaporation of ether, pale yellow oil having a characteristic fragrance was obtained. It was highly attractive to the lace wings.
Lactone considered to be contained in the steam distillate would be removed by these treatments.

\section{SEX RATIO OF THE LACE WING}

The fact that only male lace wings are selectively attracted by the active principle may be attributable to distribute few females in summer season.

One female collected by a lamp in a room was kept in a glass jar, about 1 pint in volume, to lay her eggs on July 16, 1963 in Kyoto. The larvae hatched from the eggs were reared on aphids mainly Hyalopterus arundinis FABRIcIus. Sixteen adults were emerged from their cocoons on August 4 to 5 . Ten out of sixteen individuals were identified to be male, and six were female. According to private communication from Dr. W. NAKAHARA, the sex-ratio of this lace wing is confirmed to be $1: 1$ in his specimens. It is reasonable to consider that both sexes are distributed in fields.

\section{BIOASSAY WITH MATATABILACTONE AND ISOIRIDOMYRMECIN}

A small number of the adults was attracted when matatabilactone was submitted for the biological assay. Since matatabilactone was found to be a mixture of iridomyrmecin and isoiridomyrmecin, one of them or both might be the active substance. However, infrared spectrum of the lactone suggested the presence of alcoholic component in $3400 \mathrm{~cm}^{-1}$.

Isoiridomyrmecin was also submitted for the biological tests, but none of the lace wing was attracted. Removal of lacton component from the steam distillate of the neutral substances with alkali did not change the activity.

It may be considered that the activity observed in matatabilactone is due to alcoholic impurity contained in the lactone, and iridomyrmecin and isoiridomyrmecin are not active principle. 


\section{RECEPTOR FOR THE ATTRACTANT}

When antennae of the male lace wing were removed from the basal parts, no response occurred to the neutral substance. It is evident that the receptor for this attractant located in the male antennae, but morphological aspects are remained to be solved in the future.

\section{DISCUSSION}

It has been well known in Japan that a vine plant " Matatabi ", Actinidia polygama, excits cats and other animals belonging to Felinae. Two active substances for cats have been isolated by SAKAN et al. (1959) and named as actinidine and matatabilactone. Afterwards, matatabilactone was found to be a mixture of isoiridomyrmecin and iridomyrmecin (SAKAN et al., 1960) Both compounds have already been isolated from Argentine ant, Iridomyrmex humilis by PAvaN (1950) and Fusco et al. (1955), and from Iridomyrmex nitidis by CAvill et al. $(1956,1957)$ as defense and offence substances.

It is noticeable that this plant also contains certain substance(s) which attracts the male lace wing Chrysopa septenpunctata WESMEAL.

Results of the isolation from fruits and galls of this plant indicated that the active substance for the male lace wing is neutral, soluble in ether, and steam-distillated. The infrared spectrum of the oil obtained by chromatographic separation of the steam distillate showed alcoholic bands in addition to lactone bands. After removal of the lactone with aqueous alkali, the activity still remained. Since biological tests with isoiridomyrmecin did not show any response to the insects, the active substance is not same as this lactone. The activity observed by applying matatabilactone is conclusively due to the impurity contained in the sample, and neither iridomyrmecin nor isoiridomyrmecin.

It is of interest that this attractive substance shows activity only for male and not for female although both male and female are living in fields.

This attractant seems to be a sex pheromone. However, it may be impossible to find out it from female of this lace wing. If this attractant is same as sex attractant emanated from the female sex scent glands, the females would be killed by the males. As mentioned above, the filter paper impregnated with the extract was bitten by sharp mandibles of males.

The receptor for the attractant is located in antennae of male, but the morphology and physiology of the receptor are unknown, and remained to be solved in the future.

\section{ACKNOWLEDGMENT}

The author express his sincere thanks to Dr. W. Nakahara who kindly identified lace wings, to Prof. T. SAKAN for supplying matatabilactone and kind advice for the isolation, and to Dr. Y. INOUYE for supplying isoiridomyrmecin prepared by Dr. G. W. K. Cavill. Thanks are also due to Drs. H. Hasegawa, T. Yushima, C. Hirano and $\mathrm{C}$. Tomizawa for their kind helps for the biological assay.

\section{SUMMARY}

1. A vine plant, Actinidia polygama MiQ. is highly attractive to the male lace wing, Chrysopa septenpunctata Wesmael even though both sexes distributed in fields.

2. Active principle for the male lace wing is neutral substance(s) of ether extract, and is steam-distillable. It differs. from isoiridomyrmecin and may differ from iridomyrmecin.

3. Receptors for the attractant locate in antennae of the male adult, since after removal of the antennae no response occurred to the attractant.

\section{REFERENCES}

Cavill, G. W. K., D. L. Ford and H. D. Locksley (1956) Austr. J. Chem. $9: 288 \sim 293$.

Cavill, G. W. K. and H. D. Locksley (1957) Austr. J. Chem. $10: 352 \sim 358$.

Fusco, R., R. Trave, and A. Vercellone (1955) Chem. e. Inciustr. $37: 251 \sim 258$ (Chem. Abstr. 
$50: 8451,1956)$.

IsHimori, N. (1931) Kontyu $5: 96$.

Pavan, M. (1950) Proc. 8 th Intern. Congr. Entomol., Stockholm (1948) 863 865 (Chem. Abstr. 45 : 9809, 1951).

Sakan, T., A. Fujino, F. Murai, Y. Butsugan and A. Suzur (1959) Bull. Chem. Soc. Japan
$32: 315$.

Sakan, T., A. Fujino, F. Murai, A. Suzui and Y. Butsugan (1959) Bull. Chem. Soc. Japan 32 : $1154 \sim 1155$.

TAKAGI, G. (1932) Zool. Mag. $44: 477 \sim 479$.

YANo, M. (1931) Kontyu $5: 96$.

\section{摘要 \\ マタタビに含まれるョツボシクサカゲロウ誘引物質について}

\section{石井象二郎}

\section{京都大学農学部農薬研究施設}

マタタビにヨツボシクサカゲロウ Chrysopa septenpunctata WESMAEL の雄が強く誘引されることは古く から観察されていたが，その誘引物質は不明であった。 マタタビの実およびその虫えいから有効物質の抽出分離 を試みた結果，その物質はエーテル可溶物の中性分画に 含まれ，水蒸気蒸溜により溜出される。溜出物をカラム クロマトグラフで分離を繰返し，有効成分を含む分画を
赤外吸収スペクトルで調ベた。水蒸気蒸溜溜出物中に含 まれるラクトンを分解除去しても，なお誘引性を示し た。イソイリドミルメシンには誘引性はない。誘引物質 は一種のアルコールと考えられる。

本物質の感覚受器は雄の触角に分布している。雌が誘 引されないのは，雌の個体数が特に少ないためではな w。

\section{新 刊 紹介}

The Ecology of Plant Galls: M. S. MANI 著 (1964) $15 \mathrm{~cm} \times 25 \mathrm{~cm}, 434$ ペーシ， Dr. W. Junk Pub., The Huge 邦価約 4,000 円

本書は “Monographae Biologicae”の第 12 巻と して刊行されたものである。“ゴール”とは何かの定義 に始まり，ゴールができる植物とゴールを起とさせる生 物の一般的解説，ゴールの構造，ゴールができる植物の 側からと，ゴールを起こさせる生物の側からの解説，植 物とゴールを起こさせる生物との生態的な関係など極め て多岐にわたっている。その点本書の題名「植物ゴール の生態」から受ける印象とは大分異なり，植物ゴールの 詳細な綜説と見るべきであろう。したがって，その中に
は昆虫, 線虫, バクテリヤ，果てはウイルスなどによるさ まざまな例が広く，しかもきちんと取り込まれている。 われわれ応用昆虫学関係者にとっては，ゴールの問題 はクリタマバチによる被害の蔓延によって，一躍身近な ものとなったが，その反面わが国での系統だったゴール 形成の研究は意外に少ない。また，植物ゴールの研究の 重要性は, 線虫関係者, 植物病理関係にとっては古くか ら琹められてきており，まだまだ多くの問題を含んでい る分野でもある。その点で，巻末に付された 1,300 に及 ぶ文献は魅力である。

関係者の書架に備えるべき書としておすすめしたい。

（湯嶋 健） 